\title{
The Story of Charlie Hebdo: An Analysis of European and American Newspapers ${ }^{1}$
}

Irena Wolska- Zogata

Institut of Sociology, University of Wrocław, Poland

Doi:10.5901/mjss.2015.v6n2s5p353

\begin{abstract}
The attack on Charlie Hebdo was widely spread throughout the world. It caused the reactions of politicians, celebrities and journalists. Journalists treated the attack on the editors as an attack on freedom of speech. On the other hand, the attack led to the political debate on terrorism on both sides of the Atlantic. The thesis put by the author says that the same event is the starting point for spinning two different stories. The aim of the article is to present an American and European narrative of the attack and its consequences. Research answers the questions such as: How narratives were constructed? What are the most commonly used media sources? Did materials contain additional explanations? Did they contain different points of view? Whose interests it represented? Because of access to sources of analysis were subjected to newspapers and online news sites.
\end{abstract}

Keywords: journalism, mainstream, freedom of speech, terrorism, narratives

\section{Introduction}

It is an axiom that the functioning of free media is one of the conditions necessary for the democracy to exist; it is also a widely acclaimed statement that free media have beneficial influence upon democracy. However, Hans Matthias Kepplinger, a German media scientist, proves (on the basis of the German opinion-forming press) that the presence of free media can have dysfunctional consequences for the democratic system as well.

Owing to the dominant media, news reporters perform a significant role in the production and support of social knowledge. Most of the journalists participating in the study declare that they are neutral and objective news reporters. Yet, the media function in such a way as to promote any events of negative nature, which are much more marginal in the relation to the socio-political reality that in it is presented in the media account. Thus, the reconstructed reality is deformed and distorted (Kepplinger, 1998).

Another important characteristic of the media is that they do not allow the discussion of fundamental subjects concerning most of people. Media adopt the agenda of the elites. They do not touch on the subjects that would be of interest for $80 \%$ of the society (Herman, 2006)[1].

\section{Objectivity in Media Outlets}

The objectivity principle is an issue of central importance in journalism; it comes as standard for most of the Western media. It is an established norm that news should be reported in a neutral manner and should contain as much information as possible. While there is an agreement when it comes to the objectivity principle, the attempts to define objectivity and its application are a problematic issue.

In the scientific discussion on objectivity, the starting point is a statement that objectivity should relate to the relationship between media content and reality (Kunczik, Zipfel, 2000, p. 107). The simplest view of the concept of objectivity is fact-collecting, understood in the terms of content created from information necessary in order to grasp the news on a particular event. In journalistic understanding, it means providing answers to the following questions - who? What? Where? When? And perhaps, why?

Another aspect of objectivity is impartiality, though it is difficult to provide its explicit definition. Impartiality is most valued in the description of conflict situations since they generate competing interpretations and judgements. Balanced selection of sources is a widely acclaimed norm of impartiality; it takes into account different points of views, especially if the judgements or facts are challenged. Distinguishing facts from opinions as well as choosing words that are not of evaluative nature are also aspects of impartiality.

\footnotetext{
1 Translated by Patrycja Karpińska
} 
More refined criteria are used in order to analyse the quality of media outlets; questions whether the presented facts are accurate and complete are posed. Compliance with the independent records of the event, other media outlets, witnesses and documents may be an indicator of accurateness. However, accurateness may also mean compliance of the media outlets with perception of the event by the source of information as well as the coherence of informative text.

As it is difficult to verify whether the information is complete, it leads to the questions about the relevance of presented facts. There are numerous criteria of relevance; one of them are theoretical assumptions on how the media outlets should report. In theory, relevance is identified with what is crucially important from a long-term historical perspective and what favours the functioning of the society. The second criterion is journalists' opinion on the relevance. The study of American journalists shows a clear discrepancy between the notions of 'significance' and 'interest' (McQuail 1992, p. 218). The following aspects are relevant for the journalists: firstly, what affects people; secondly, what is interesting and unusual; thirdly, what is up-to-date and relates to the local or global events. On the bases of his own experience, a German TV journalist describes what is objective in the following way, 'objective is what we like, what we can use, what we are eager to hear and what confirms our own opinion' (Kunczik, Zipfel, p. 111) [2]. Hans Kepplinger used a term 'instrumental revision' for the journalists' tendency to select from all available information those which conform to their own views and editorial staffs' stance.

By presenting and justifying the choice of particular topics and frames of interpretation, journalists are one of the most significant social groups which influence formation of social representations of issues, new phenomena, conflicts and catastrophes (Lisowska-Magdziarz, 2014).

\section{Attributes of Information}

On the basis of their research, Johan Galtung and Mari Ruge (1965, after McQuail, 2005, p. 311) distinguish three basic groups of factors that influence the value of information; thus, the properties that make an event material worth publishing. These are organisational, genre-related and socio-cultural factors. Organisational factors often have an ideological nature and they are the most unavoidable as well as universal. Collecting material requires certain organisation of work; hence, it favours events that take place, for instance, near major information centres with welldeveloped infrastructure. Genre-related factors include preference of the events which can maintain the audience's interest through the reference to earlier facts or events which can be easily inscribed on existing frames, e. g. conflict, crisis etc. Finally, socio-cultural factors are rooted in the features characterising Western culture. These are: interest in the elites, brutal and drastic events, close-proximity of the event, personalisation of the event, tragedy, and legibility.

\section{Legitimisation of the News}

Media need sources of information. In order to legitimise the media outlets, producers of information refer mostly to the official authorities and common sense. This inevitable form of legitimising information, which disguises itself as a safeguard of objectivity, can lead to the distortion of reality. According to Stephen Reese, August Grant and Lucig Danielian, journalists refer to a restricted group of sources, which makes it impossible to reveal multiple points of view. The authors of the study suggest that '[b]y relying on a common and often narrow network of sources ... the news media contribute to [a] systematic convergence on the conventional wisdom, the largely unquestioned consensus views held by journalists, power-holders and many audience members' ( Reese, Grant, Danielian,1994)

In the times of crisis, media derive their news from foreign media and official local sources, making the interpretation of events biased.

\section{Framing Theory}

One of the conclusions based on the study of the content of media outlets is that they have a predictable construction. As Park observes it, 'if it is the unexpected that happens it is not the wholly unexpected which gets into the news. The events that have made news in the past, as in the present, are actually expected things ... it is on the whole the accidents and incidents that the public is prepared for ... the things that one fears and that one hopes for that make news' (1940/1967, after McQuail 2010, p. 378).

Gaye Tuchman (1978) refers in this context to Erving Goffman, who is an author of the frame concept which serves as a tool necessary for the organisation of dispersed fragments of experience or information. Frames in information are applied as frames of reference, i. e. context and theme. In the context of journalism, meaning of topics is a result of reference to a particular informational value which connects one event with another. According to Entman 
(1993), the application of frames consists of the selection and hierarchy of priorities. Frames define the issue in question, diagnose the causes, impose moral judgements and suggest the solutions to those issues.

Journalists cannot escape from partiality, to say the least, because their informants also apply frames conforming to their aims. Frames of interpretation make an individual capable of using information. Frames applied by the media are patterns of selection, which allow both to highlight certain fragments of reality and to omit others (Gitlin, 1980).

Depending on the country and media system, different frames - governed by political factors and public opinion are applied to describe the same event.

\section{Media Content as Narrative}

Most of the media content tells a story about something in a well-ordered and predictable manner. The most important function ascribed to the narrative is the facilitation of understanding of the news report meaning. This aim is fulfilled in following two ways: either through arranging actions and events in logical sequence (chronological, causal) or through the introduction of regular and realistic persons and places. Narrative helps to understand the logic behind human actions whereas fragmentary observations form coherent whole.

\section{Subject of the Study}

The subject of analysis are online editions of French, British and American newspapers issued from the $7^{\text {th }}$ day of January, 2015 to the $22^{\text {nd }}$ day of February, 2015. Only the articles which titles directly referred to the events at Charlie Hebdo headquarters from the $7^{\text {th }}$ day of January, 2015 were analysed.

In accordance with the agenda-setting theory, media indicate certain events to be the most important events of a given day; consequently, they are perceived as such by the audience. The highest amount of news about Charlie Hebdo was published within the first 7 days. This is understandable due to the novelty of the news. On the $14^{\text {th }}$ day of January, the first issue after the shooting is published and also immediately becomes a national topic. Media report on endless queues and millions of sold copies. Six weeks later, repercussion of the shooting are still present in the media but to a lesser degree.

\section{Attack on Charlie Hebdo}

First reports from the $7^{\text {th }}$ day of January, 2015 on the attack on satirical magazine Charlie Hebdo headquarters were of factual nature. The undermentioned chronology of the events was retrieved from L'essentiel online. In the first minutes, media quote the accounts of witnesses and the police. All of them provide information that attackers screamed 'Allahu Akbar!' and opened fire. The source of this information is a journalist from Premières Lignes information agency, who posted also a video, on which a cry 'Allahu Akbar!' and shots can be heard http: //www. lessentiel. lu/fr/news/france/ story/22976860). During the first hours, the French police are the most important source of information, who inform on the number of victims and the chase after attackers. On 12: 44 PM the French president François Hollande arrives at the crime scene and says that this was an act of extreme cruelty and there are no doubts that it was a 'terrorist attack. ' Later, the French media inform that British Prime Minister David Cameron posted a twit, in which he condemned the attack and expressed solidarity with France 'in the fight against terror and defending the freedom of the press. ' L'essentiel posts also a twit by Laurent Mosar, MP Deputy Speaker of Luxemburg, who says, 'I am staggered by and terrified of the brutality and cowardice on this frontal attack on the freedom of speech'. [3]

At 1: 19 PM the information about number of victims is posted - 12 people were killed.

At 6 PM, the statement of former editor of Charb et Tignous Mourad Boudjellal is issued. He refers to the attack on Charlie Hebdo headquarters as the ' $9 / 11$ of the press. 'At the same time, the press conference of the Public Prosecutor's Office in Paris begins.

L'essentiel posts information that Stephane Charbonnier (Charb), one of the murdered caricaturists, was in 2013 on the Al-Qaeda's most wanted list for his crimes against Islam. The list was published in English by the Internet newspaper Inspire.

According to the police, aggressors were well-equipped (for example, in automatic weapons) and well-prepared; they acted calmly and methodically (AFP). In one of the cars (Citroën C3) abandoned by the assassins, ID card of one of the attackers, Saïd Kouachi, was found (www. lefigaro. fr).

On the same day, 'The National Union of Journalists (NUJ) has described the shooting at the Charlie Hebdo offices in Paris today (January 7) as 'an attempt to assassinate the free press. ' (Nissim, 2015, Jan. 7). 
Michelle Stanistreet, a general secretary of NUJ, stated that '[t]he newspaper had already been the subject of attacks by people who want to suppress democracy and freedom of speech' (ibid. ).

\section{The Day After}

Directly after the attack on Charlie Hebdo headquarters, editorial staff of European magazines express their solidarity with the murdered cartoonists. Titles and headlines in the magazines clearly indicate that it was a terrorist attack, which shocked people all over the world. The Huffington Post writes that '[n]ewspapers around the world are rallying around Charlie Hebdo, the French satirical newspaper targeted in a terror attack on Wednesday in which 12 people were killed' (Mazza, 2015, Jan. 7).

The newspaper publishes also front pages of the magazines from Great Britain, Germany, France, and Canada, showing how the world reacted to the attack. [4] On the front page, The Independent publishes an illustration, which is described by The Huffington Post as 'a message for the terrorists. ' The drawing shows a middle finger protruding from the bloodstained page of Charlie Hebdo newspaper. Similar illustration, with a middle finger shaped as a pencil, is published by L'Echo, a newspaper from the Limousin region of France. The Huffington Post presents also an illustration from L'Équipe, French sports magazine, who 'depicted the attack as a contest between Liberte (freedom) and Barbarie (barbarity). ' As The Huffington Post reports, 'in the hours after the attack, "Je Suis Charlie" ("I Am Charlie") became a cry of solidarity, both on the streets of Paris and online, where \#JeSuisCharlie was trending on Twitter. Many newspapers also use the phrase, including France's L'Independant' (ibid. ).

In Canada, The Toronto Sun publishes an illustration, on which a cartoonist, with a bloodstained hand, draws by means of a pencil with an inscription 'Freedom. ' Next to the illustration, there is a caption, 'Draw strength. '

The most significant American media react with remarkable restraint and carefulness. They do not show the caricatures from Charlie Hebdo magazine that were the reason for terroristic attack.

Officially, President Barack Obama condemns the terroristic attack in Paris and declares solidarity with the French; however, two years before the attack happened, the French magazine had been criticised by the White House for publishing Mohammed's caricatures which had led to Muslims' protests in Arab countries.

CNN Senior Editorial Director Richard Griffiths sends to his employees such an 'Although we are not at this time showing the Charlie Hebdo cartoons of the Prophet considered offensive by many Muslims, platforms are encouraged to verbally describe the cartoons in detail. This is key to understanding the nature of the attack on the magazine and the tension between free expression and respect for religion. Video or stills of street protests showing Parisians holding up copies of the offensive cartoons, if shot wide, are also OK. Avoid close-ups of the cartoons that make them clearly legible. ' (Gold, 2015, Jan. 7).

A spokesperson of NBC, which owns several channels, announces that '[0]ur NBC News Group Standards team has sent guidance to NBC News, MSNBC, and CNBC not to show headlines or cartoons that could be viewed as insensitive or offensive' (Wilstein, 2015, Jan. 7).

New York Daily News shows archive photographs of one of the twelve victims - Stephane Charbonnier - who holds the magazine; yet the front page with a caricature is blurred by the New York Daily News graphics.

New York Times spokesman states that '[u]nder Times standards, we do not normally publish images or other material deliberately intended to offend religious sensibilities. After careful consideration, Times editors decided that describing the cartoons in question would give readers sufficient information to understand today's story. ' (Smith, 2015, Jan. 8)

Such media outlets as Bloomberg, Vox, Huffington Post and Daily Beast do not follow this trend. Some of them demonstratively show numerous caricatures, including the most provocative ones and those criticised by the Muslims (Gazeta Wyborcza, 2015).

\section{Al-Qaeda and the Climate of Fear}

On the $8^{\text {th }}$ day of January, 2015 The Guardian quotes French public poll in the attempt to explain the reasons standing behind the attack on Charlie Hebdo. The data from the poll indicates that 'in France $80 \%$ of French people judged the risk of terrorism in the country as high - a record level. [5] Greater than figures post- 9/11, the London bombings, the killing of Osama bin Laden and the Boston marathon attack' ( Nardelli, 2015, Jan. 8).

Citing scientific research is an effective way to legitimise and give credence to information. After the murder of a dozen or so people committed by the French Muslims, there is nothing that would appeal to people more than the results of the study, which reveal that '[l]ooking at the Muslim community specifically, $63 \%$ of French voters in the Ipsos study 
said that Islam isn't compatible with the values of French society. Looking at other religious beliefs, $24 \%$ said the same for Judaism and $9 \%$ for Catholicism. Almost three-quarters, 74\%, said Muslims want to impose their values on others Overall, just under $70 \%$ of respondents said that religious fundamentalism is a worrying problem that needs to be seriously dealt with. These views are probably not helped by a noticeable gap between perception and reality' (ibid. ).

However, the editorial staff makes it clear that '[n]umbers alone cannot explain a tragedy, but they can help provide a few of the threads, and the context and clarity needed to better understand complexity' (ibid. ).

On the $9^{\text {th }}$ day of January, Le parisien, referring to AFP, reports that Kouachi brothers, suspected of the attack on Charlie Hebdo, were in the USA's Terrorist Identities Datamart Environment (TIDE) system and that Said, older of the two brothers, was trained in Yemen (www. leparisien. fr). [6]

Richard Clarke, a former White House counter terrorism expert, told ABC news: 'This does not look at all like a spontaneous attack or a lone wolf attack," he told ABC News. "This looks like a team that was selected, trained, probably over the course of a long period of time, and sent in with this particular target in mind. ' (Millward, 2015, Jan 9)

On the $9^{\text {th }}$ day of January, NY Times, referring to AP, publishes an article which opens with a statement that the hunt of the two suspected of terrorism has transformed into the fear that the terrorists strike again in the centre of Paris. There is an investigation taking place in order to establish whether the attack was co-ordinated and, if yes, by whom. The profile of Kouachi brothers is described in order to justify these fears; the description comprises their connection to Yemen's Al-Qaeda. Furthermore, the statement is legitimised by quotations of 'Michel Thooris, the secretary-general of France's police labor union, who told AP he didn't believe these were "three people isolated in their little world. " "This could very well be a little cell," he said. "There are probably more than three people. ' (NYTimes, 2015, Jan 9).

Furthermore, as NY Times writes, 'French Prime Minister Manuel Valls, speaking in a TV interview late Friday, also indicated [that] authorities are bracing for the possibility of new attacks. ' They quote such Valls's phrases as, 'We are facing a major challenge' and 'very determined individuals. ' (ibid. )

NY Times, referring to an anonymous American official, claims that Kouachi had travelled to Yemen to train with Al-Qaeda. Furthermore, one of the brothers was sentenced for terrorism whereas the other one was on the USA's no-fly list. According to the official, investigating officers are still trying to determine whether the attack on Charlie Hebdo headquarters was organised by Al-Qaeda or by the brothers themselves.

The official also states that no evidence that the brothers contacted anyone in the United States has been found; however, this issue is still subject to investigation.

CNN publishes the same news. CNN adds that the US agencies had observed Said and his younger brother Cherif even before the attack. Both of them were on the USA's no-fly list. According to CNN, American services are trying to determine whether the attack took place on Yemeni Al-Qaeda's order; so far, there is no proof to indicate so.

\section{Where is Charlie?}

Week after the tragic events, a new issue of Charlie Hebdo is published. On the $13^{\text {th }}$ day of January, 2015 The Guardian publishes an article with such a warning: 'this article contains the image of the magazine cover, which some may find offensive' (Penketh, Weaver, 2015, Jan. 13). The Guardian reminds that 12 people died in the tragic events from the $7^{\text {th }}$ day of January. Then, the content of the newest Charlie Hebdo's issue is described as follows: 'The cover shows the prophet shedding a tear and holding up a sign reading "Je suis Charlie" in sympathy with the dead journalists. The headline says "All is forgiven. "' At the same time, The Guardian refers to an interview with Zineb El Rhazoui, one of the Charlie Hebdo's writers who survived the attack and contributed to the new issue of the magazine. As The Guardian reports, '[t]he columnist said the cover was a call to forgive the terrorists who murdered her colleagues last week, saying she did not feel hate towards Chérif and Saïd Kouachi despite their deadly attack on the magazine, and urged Muslims to accept humour. "We don't feel any hate to them. We know that the struggle is not with them as people, but the struggle is with an ideology," she told BBC Radio 4's Today programme. '

According to the Guardian, the words spoken by Zineb El Rhazoui - 'The two terrorists who killed our colleagues, we cannot feel any hate ... The mobilisation that happened in France after this horrible crime must open the door to forgiveness. Everyone must think about this forgiveness' - are an answer to the president of British Muslim Association Omer el-Hamdoon, who said, 'My reaction to the cartoon is disgust, but tending more to annoyance as well because I feel that what's happening here is not that different from what we witnessed back in 2005 with the Danish cartoons when media outlets went into a cycle of just publishing the cartoons just to show defiance. And what that caused is more offence.'

El Rhazoui explains also that her colleagues 'died because of small drawings, because of a joke, but what happen to us was not a joke. Muslims must understand that we in Charlie Hebdo just consider Islam as a normal religion just like 
any other religion in France. Islam must accept to be treated like all the other religions in this country. And they must accept humour also' (ibid. ).

On the $14^{\text {th }}$ day of January, 2015 John Lichfield, Parisian correspondent of The Independent, reports as follows: 'Where's Charlie? Parisians scrambled and, against all their instincts, queued this morning for a copy of the first edition of Charlie Hebdo since last week's massacre. Although 3 million copies are to be printed, most newsagents and news kiosks received scarcely more copies than a usual week. By 7am, most newsstands [sic] in the capital were sold out. Long queues formed outside those which opened later'.

When Europe and the USA are flushed with feverish excitement at the newest issue of Charlie Hebdo, in nonChristian parts of the world there are protests against the caricatures; and those are not only verbal.

On the $14^{\text {th }}$ day of January, a week after the attack, NY Times, referring to Reuters, provides information that even though Muslim world leaders condemn the attack on Charlie Hebdo, they consider the publication of another Muhammad's caricature to be unnecessary provocation and a sign of the lack of respect (NYTimes, 2015, Jan. 14).

The Huffington Post reports on the Muslim reactions in the article 'Muslims Around The World React To Charlie Hebdo's New Cover' (Kuruvilla, 2015 Jan. 14).

Two days later, The Associated Press and Reuters publish the news about the anti-Charlie protests, which took place in Nigeria. The Huffington Post writes that 'Niger's interior minister says at least four people have died and dozens have been wounded in violent protests against French newspaper Charlie Hebdo's publication of a cartoon of the Prophet Muhammad' (Huffingtonpost, 2015, Jan. 16).

BBC, NY Times, NBCnews, Euronews quoted Reuters that "[i]n Niger, demonstrators said they were angered by the latest front cover of Charlie Hebdo this week, which despite the Paris killings again featured a cartoon of Mohammad' (Reuters 2015, Jan 16).

\section{Alternative Voices. Criticism of the Mainstream Narrative}

Media reaction after the attack on Charlie Hebdo headquarters and the way in which narrative was created have faced critical analysis in both United Stated and the Middle East.

On the day of the attack, France Internationale Radio (RFI) informs that one of the persons who survived the attack on Charlie Hebdo is Sigolène Vinson, a freelance writer and novelist. After the tragedy, Vinson tells RFI that she survived because one of the attackers said, "We do not kill women, but you have to convert to Islam and veil yourself," before shouting "Allah Akbar" ' (RFI, 2015, Jan. 7).

George Conger (2015, Jan. 13) describes in his article 'NYT vs RFI Over Made-Up Quotes' how NY Times altered Vinson's statement from the above mentioned interview in its text, which is published two days after the attack. [7] In the first version of the text, NY Times publishes the following quote:

'Instead, she told French news media, the man said, "I'm not going to kill you because you're a woman, we don't kill women, but you must convert to Islam, read the Quran and cover yourself," she recalled'.

However, the online version of NY Times publishes a quote, "Don't be afraid, calm down, I won't kill you," the gunman told her in a steady voice, with a calm look in his eyes, she recalled. "You are a woman. But think about what you're doing. It's not right"'.

NY Times is criticised for the rewriting of the quote by Jim Teacher, who claims the magazine to act cowardly. Jim Teacher says, '[h]ere's the latest example of the New York Times censoring itself to avoid offending Muslims after an act of Islamic terror. Nothing about telling her to convert to Islam. Nothing about telling her to read the Quran. Nothing about telling her to cover her face' (Conger, 2015, Jan. 13).

Soon enough, New York Times changes the text again. In the new version, paragraph on Vinson is as follows:

'She disputed a quotation attributed to her and carried on the website of the French radio service RFI stating that the gunman had told her she should convert to Islam, read the Quran and cover herself. Instead, she told The New York Times in an interview, the gunman told her: "Don't be afraid, calm down, I won't kill you. " He spoke in a steady voice, she said, with a calm look in his eyes, saying: "You are a woman. But think about what you're doing. It's not right. "Then she said he turned to his partner, who was still shooting, and shouted: "We don't shoot women! We don't shoot women! We don't shoot women!"'

Both Mirror (Lines, 2015, Jan. 8) and The Guardian (Willsher, 2015 Jan. 14) cite Vinson's statement in the version published by RFI.

Media outrage over the attack on the freedom of speech is also questioned by Noam Chomsky. [8] In his article for CNN, Chomsky criticises the reactions of politicians and journalists who sought an explanation for the attack on Charlie Hebdo headquarters in the Islam culture. He writes that 'The New York Times described the assault as a "clash of 
civilizations," but was corrected by Times columnist Anand Giridharadas, who tweeted that it was "Not \& never a war of civilizations or between them. But a war FOR civilization against groups on the other side of that line. \#CharlieHebdo"' (Chomsky, 2015, Jan. 19).

Chomsky quotes also a report by correspondent Steven Erlanger who described in detail the events from Paris for New York Times in such words: 'a day of sirens, helicopters in the air, frantic news bulletins; of police cordons and anxious crowds; of young children led away from schools to safety. It was a day, like the previous two, of blood and horror in and around Paris.

Chomsky criticises the Erlanger's description of the events in Paris and recalls another event, also reported by the said Erlanger, which took place on the 2nd day of April, 1999. On this day, NATO launched a bombing raid on the headquarters of Serbian television, in the event of which 16 journalists died. Western media described this event as an attempt to overthrow the regime of the President Slobodan Milošević. Chomsky cites the words of Kenneth Bacon, the spokesman of the Pentagon at that time, who said at the press conference in Washington that 'Serb TV is as much a part of Milosevic's murder machine as his military is. ' With a hint of sarcasm, Chomsky comments that '[t]here were no demonstrations or cries of outrage, no chants of "We are RTV," no inquiries into the roots of the attack in Christian culture and history. On the contrary, the attack on the press was lauded. The highly regarded U. S. diplomat Richard Holbrooke, then envoy to Yugoslavia, described the successful attack on RTV as "an enormously important and, I think, positive development," a sentiment echoed by others' (ibid. ).

In the same article, Chomsky reminds that many journalists died in the summer of 2014, during the Israeli attacks in Gaza as well as in Latin America. He concludes that '[b]ut again, not an assault on freedom of press within living memory' (ibid. ).

On the other hand, Jamil Khader, a dean of research and professor of English at Bethlehem University in Palestine, publishes in Aljazeera his opinion on the Western media narrative after the attack on Charlie Hebdo headquarters. Referring to the events of 9/11, media apply a frame or a point of reference, which is well-known and recognised in the Western world - Islam terrorism (2015, Jan. 14).

According to Khader, "[d]espite residues of the Islamophobic rhetoric in representing Islamic terrorism in mainstream media, there is a paradigm shift in the way that media and politicians are framing these incidents. The current neoliberal framework pushes away any radical solution to the problem of fundamentalist-terrorism' (ibid. ).

Brandon Turbeville also voiced a critical opinion on the issue of media. According to Tuberville (2015, Jan. 8), 'the pathetic left-wing attempts to blame the victim for incitement and focuses on the need to become more politically correct, self-censoring, and linguistically minimal. The vast majority in the middle, however, believe the official mainstream version of events, quake in their boots, and move on to the next form of entertainment provided to them by the culture creators without a second thought. Yet, as is almost always the case, there is much more to the story than is being reported by mainstream outlets. There exist a number of questionable details regarding the Charlie Hebdo attack, as well as the relatively open control over terrorist groups and Islamic jihadists by the French intelligence apparatus, the US, and NATO' (ibid. ).

\section{Conclusions}

The presented analysis does not exhaust the topic; it is an attempt to understand how the media form narrative in a threatening situation and how they unanimously refer to the same frames of reference, well-known from the past, as well as how the geographic, social and cultural proximity of the threat influences its perception.

Media plurality, such as in the case of Charlie Hebdo, do not result in different narratives. It is difficult to discuss the competition among the news; we rather deal with consumption of the alike news by the most significant European and American media outlets. Only few sources of information serve as a point of reference. Two press agencies dominate; these are AP and AFP. European leaders are often quoted. Histories are told from the perspective of an individual; it gives the human dimension to and domestic character of a tragedy - 'this happened to our friends, neighbours'.

Two narratives dominate in the analysed media outlets; the first one refers to the freedom of speech, while the second one to the fight with terrorism.

In the West, the attack on Charlie Hebdo headquarters has become a symbol of the fight for freedom of speech. Slogan 'Je suis Charlie' ('I am Charlie') has become both a symbol of solidarity with the victims and a weapon in the fight with those who threaten the freedom of speech. Journalists, celebrities, and politicians widely and publicly criticise the attack. 3 million of sold first Charlie Hebdo copies after the attack is also a form of solidarity. The Associated Press reports that this issue was published in many languages and that 50 times more copies were printed than usual (Kuruvilla, 2015). [9] 
The comparison of the attack on Charlie Hebdo to the attack on WTC in 2001 becomes a ready frame to create the narrative of spreading terrorism and the need to fight it. Even though American media (except for few Internet media) unofficially adopt the rule of not posting content which could be provocative to Muslims, they willingly refer to the narrative of fight with terrorism by looking for the connection between Kouachi brothers and Al-Qaeda. American media more frequently refer to the American officials than press agencies.

European media apply a wider frame and they analyse the Parisian events in the context of current European issue, i. e. the immigration of Muslims to Europe. They see immigrants as a threat to the European culture. In the analysis of the narrative in the main European media, references to terrorism and Islamic immigrants, who constitute a real threat to the fundamental European values, can be perceived. They underline the Islamic extremism by repeating that the satirical magazine mocked all religions, including the cartoons of the Pope, yet only Muslims reacted in such a violent way.

According to the Western media, Charlie Hebdo is '[f]ar from targeting Muslims in particular, the satirical newspaper has ridiculed everyone from English people to the Pope' (Lewis, L. , White, A. (2015, Jan. 7, ).

The Independent explains to its readers that 'Charlie Hebdo is a left-leaning French weekly satirical magazine known for its provocative tone and anti-religious stance, and features cartoons, reports, polemics and jokes. The cartoonled secular magazine mocks religious faiths of all kinds, defends women's rights, and satirises public figures, from politicians to judges, bankers, and religious founders' (Eleftherio- Smith, 2015, Jan. 7).

On the other hand, according to the non-central European stance, 'much of their [Charlie Hebdo's] material is offensive, Islamophobic (and anti-Semitic, as well as racist, sexist, and homophobic), and the argument that it is "freedom of speech" is a very crude way to allow offensive material to be published' (Yazan al-Saadi, 2015, Jan. 8).

The enormous publicity over the first Charlie Hebdo issue after the attack (14th day of January, 2015) resembles the mythological Phoenix arising from the ashes. Despite the attempt to terrorise the journalists, the magazine arises even stronger.

The official outrage on the attack on the freedom of speech and press blends with critical opinions on hypocrisy and lack of solidarity with journalists murdered in different parts of the world.

American media allow more critical opinions to be voiced. Muslim Frenchs comment in the reports; criticism of Charlie Hebdo by European editors [10] and French immigration policy are reminded. But on the day of the attack on Charlie Hebdo headquarters, NBC reports the event on the basis of sole source - the officials of US government (Conger, 2015, Jan. 10).

In general, the analysis of available mainstream media outlets proves that:

Opinions of the persons of high status and official positions are over-represented in the news reported by the media.

Media focus predominantly on the members of political and social elites.

Universal values, strengthening the status quo, are the most underlined social values. The freedom of speech is presented as the most significant Western value and the heart of democracy.

Foreign news focuses on the closest, richest, and strongest countries. Reports from countries outside Europe are limited to short news agencies reports.

Media outlets display a tendency towards ethnocentrism. European countries represent the most regarded values: freedom, brotherhood, tolerance.

Ethnic minorities and immigrants are marginalised or stigmatised. Islamic culture threatens the Western values and, thus, the extremism should be fought with (see McQuail, 2005).

To sum up, we are the witnesses of the creation of a new frame; a frame, which will be undoubtedly used by the media to describe similar conflicts in the future.

\section{References}

Chomsky, N. (2001, October 18). The New War Against Terror. Retrieved from http: //www. chomsky. info/talks/20011018. htm

Chomsky, N. (2015, Jan. 19). Paris attacks shows hypocrisy of West's outrage. Retrieved from http: //edition.cnn.com/2015/01/19 lopinion/charlie-hebdo-noam-chomsky/.

Conger, G. (2015, Jan. 10). Charlie Hebdo Coverage and the Fog of War. Retrieved from http: //themediaproject. org/article/charliehebdo-coverage-and-fog-war?page $=0,0$.

Conger, G. (2015, Jan. 13). NYT vs RFI Over Made-Up Quotes. Retrieved from http: //themediaproject. org/article/nyt-vs-rfi-madequotes?page=full

Eleftheriou- Smith, L. (2015, Jan. 7) Charlie Hebdo: A profile of the satirical magazine.

The independent. Retrieved from http: //www. independent. co. uk/news/world/europe/charlie-hebdo-a-profile-of-the-french-satirical- 
magazine-9962720. html.

Entnam, R. M. (1993). Framing US coverage of the international news: contrasts in narratives of the KAL and Iran air incidents, Journal of Communication, vol. 43 (4), (pp. 51-58).

Galtung, J. , Ruge M. H. (1965). The structure of foreign news, Journal of Peace Research vol. 1, ( pp. 64-90).

Gazeta Wyborcza, ( 2015, Jan. 8). Powściagliwi i ostrożni. Amerykańskie media po zamachu. Retrieved from http: I/wyborcza. pl/1,75477,17223258,Powsciagliwi_i_ostrozni_amerykanskie_media_po_zamachu. html.

Gitlin, T. (1980). The Whole World Is Watching: Mass Media in the Making and Unmaking of tin-New Left, Berkeley: University of California Press.

Gold, H. (2015, Jan. 7). Internal CNN memo: 'We are not at this time showing the Charlie Hebdo cartoons'. Retrieved from http: //www. politico. com/blogs/media/2015/01/internal-cnn-memo-we-are-not-at-this-time-showing-200711. html.

Herman, E. (2006, June 12). Propaganda w wolnej prasie. Intervied by David Ross, Retrieved from http: //cia.media.pl/edward_ herman_propaganda_w_wolnej_prasie.

Huffingtonpost, ( 2015, Jan. 16). 4 Killed In Violent Anti-Charlie Hebdo Protests In Niger. By AP. Retrieved from http: //www. huffingtonpost. com/2015/01/16/charlie-hebdo-niger-4-killed-in-violent-protests_n_6489352. html.

http: //www. leparisien. fr/charlie-hebdo/attentat-a-charlie-hebdo-said-kouachi-entraine-par-al-qaida-au-yemen-09-01-2015-

Kepplinger, H. M. (1998). Die Demontage der Politik in der Informationsgesellschaft, Freiburg/München.

Khader, J. (2015, Jan. 14). A new narrative after Charlie Hebdo http: //www. aljazeera. com/indepth/opinion/2015/01/islam-terrorismparis-charlie-h-201511210460391695. html.

Kunczik M. , Zipfel A. , (2000). Einfuhrung in die Publizistik - und Kommunikationswissenschaft (Polish edition): Scholar.

Kuruvilla ,C. (2015, Jan. 14). Muslims Around The World React To Charlie Hebdo's New Cover. Huffingtonpost Retrieved from http: //www. huffingtonpost. com/2015/01/14/muslim-charlie-hebdo-over_n_6473050. html.

Lewis, L. , White, A. (2015, Jan. 7, ). 12 Striking Charlie Hebdo Front Covers, BuzzFeed, Retrieved from

http: //www. buzzfeed. com/lukelewis/charlie-hebdo-front-covers

Lichfield, J. (2015, Jan. 14). Charlie Hebdo: Inside the first edition since the Paris massacre. The Independent. Retrieved from http: //www. independent. co. uk/news/world/europe/charlie-hebdo-inside-the-first-edition-since-the-paris-massacre-9976559. html.

Lines, A. (2015, Jan. 8). Charlie Hebdo: Journalist spared death by terrorists during brutal attack at magazine office 'because she's a woman', Mirror, Retrieved from http: //www. mirror. co. uk/news/world-news/charlie-hebdo-journalist-spared-death-4944715.

Lisowska-Magdziarz, M. (2014). Władza24. Dziennikarz informacyjny w świecie polityki zmediatyzowanej. e- Politikon No 12, winter 2014. Retrieved from http: //oapuw. pl/wp-content/uploads/2014/12/e-Politikon-12-2014. pdf.

Mazza, E. (2015, Jan. 7). Newspapers React To Charlie Hebdo Attack With Show Of Solidarity On Front Pages, Hufftingtonpost, Retrieved from http: //www. huffingtonpost. com/2015/01/07/charlie-hebdo-front-pages_n_6433722. html.

McQuail, D. (1992). Media Performance: Mass Communication and the Public Interest, London: Sage.

McQuail, D. (2005). McQuail's Mass Communication Theory, 5th edition: Sage Publications.

McQuail, D. (2010). McQuail's Mass Communication Theory, 6th edition: Sage Publications.

Millward, (2015, Jan 9). Paris shooting: suspected killers 'were on no fly lists'. The telegraph Retrieved from http: //www. telegraph. co. uk/news/worldnews/europe/france/11334524/Paris-shooting-suspected-killers-were-on-no-fly-lists. html.

Nardelli, A. (2015, Jan. 8). From margins to mainstream: the rapid shift in French public opinion. The Guardian Retrieved from http: //www. theguardian. com/world/datablog/2015/jan/08/french-public-opinion-charlie-hebdo-attacks .

Nissim, M. (2015, Jan. 7) Charlie Hebdo killings are attempt to assassinate free press, says NUJ

Retrieved from http: //www.digitalspy.co.uk/media/news/a619921/charlie-hebdo-killings-are-attempt-to-assassinate-free-press-says-nuj. $\mathrm{html}$.

NYTimes, (2015, Jan 9) . French Probe Terror Suspect Links; New Attacks May Be Ahead By THE ASSOCIATED PRESS. International New York Times

Retrieved from http: //www. nytimes. com/aponline/2015/01/08/world/europe/ap-eu-france-attack-suspects. html. (NYTimes, 2015, Jan. 14). Anger, Calls for Calm in Middle East Over New Charlie Cartoons. By Reuters. International New York Times

http: //www. nytimes. com/reuters/2015/01/14/world/middleeast/14reuters-france-shooting-muslims. html.

Park,R. (1940). News as a form of knowledge. In R. H. Turner (Ed. ), On Social Control and Collective Behavior, (pp. 32-52), Chicago: Chicago University Press.

Penketh, A. , Weaver,M. ( 2015, Jan. 13). Charlie Hebdo: first cover since terror attack depicts prophet Muhammad. The Guardian, Retrieved from http: //www. theguardian. com/media/2015/jan/13/charlie-hebdo-cover-magazine-prophet-muhammad

Reese, S. D. , Grant, A. , Danielian, L. H. (1994). 'The structure of news sources on television: a network analysis of "CBS News", "Nightline", "McNeil/Lehrer" and "This Week With David Brinkley," Journal of Communication, 44 (2): 64-83.

Reuters (2015, Jan 16). Retrieved from http: //www. reuters. com/article/2015/01/16/us-niger-protest-violence-idUSKBNOKP 2EO20150 116.

RFI ( 2015, Jan. 7). Charlie Hebdo: ce qu'on sait de l'attentat et de l'enquête. Retrievd from http: //www. rfi. fr/france/2min/20150107charlie-hebdo-reactions-attaque-journal-morts-hollande-cameron-terrorismel .

Smith, S. (2015, Jan. 8). New York Times' Public Editor Responds to the newspaper Not Publishing Charlie Hebdo Cartoons. Retrieved from http: //www.imediaethics. org/News/4989/New_york_times_public_editor_responds_to_the_newspaper_not_publishing_ charlie_hebdo_cartoons_.php.

Turbeville, B. (2015, Jan. 8) 6 Points To Consider When Analyzing The Charlie Hebdo Attacks. Retrieved from http: //www. activistpost. 
com/2015/01/6-points-to-consider-when-analyzing. html.

Tuchman, G. (1978). Making News: a study in the Construction of Reality, New York: Free.

Willsher, K. (2015 Jan. 14). Charlie Hebdo killings: 'Don't be afraid. I won't kill you. You're a woman'. The Guardian. Retrieved from http: I/www. theguardian. com/world/2015/jan/14/charlie-hebdo-killings-survivor-story

Wilstein, M. ( 2015, Jan. 7). NBC News and MSNBC Join CNN in Not Showing Charlie Hebdo Cartoons, Retrieved from http: //www. mediaite. com/tv/nbc-news-and-msnbc-join-cnn-in-not-showing-charlie-hebdo-cartoons/.

Yazan al-Saadi, ( 2015, Jan. 8) On Charlie Hedbo, freedom of speech, terrorism \& Value of lives Retrieved from http: I/muftah. org/charlie-hebdo-freedom-speech-terrorism-value-lives/\#. VPR3KPmG964.

\section{Footnotes}

1. Ed Herman, Professor Emeritus of Wharton School, University of Pennsylvania; co-author (with Noam Chomsky) of the breakthrough book 'Manufacturing Consent'.

2. Translation mine: PK

3. 'Je suis abasourdi et horrifié par la brutalité et la lâcheté de cette attaque frontale à la liberté d'expression' (retrieved from http: //www. lessentiel. lu/fr/news/france/story/22976860). L'essentiel was established in 2007 and is published in French

4. It's mean rich Western countries (I. W-Z).

5. A poll released in France by Ifop on the $5^{\text {th }}$ day of January, 2015.

6. Le parisien refers to the AFP whereas the same information appeared as own information on the 8th Day of January at http: //news. yahoo. com/terror-suspects-in-charlie-hebdo-massacre-were-on-u-s---no-fly--list-212840229. html 7. http: //www. nytimes. com/2015/01/09/world/europe/survivors-retrace-a-scene-of-horror-at-charlie-hebdo. html 8. Noam Chomsky, Professor Emeritus of Linguistics, is known for his critical media analysis and critical approach towards internal and foreign politics.

9. Both official agencies (AP, see: http: //www. huffingtonpost. com/2015/01/27/free-speech-france-charliehebdo_n_6550240. html ) and alterative media condemn the French government for applying double standards. The dominant gesture of the fight for the freedom of speech clashes with the actions of French government, who 'arrested 54 people for offensive comments (not actions) deemed to be "defending" or "glorifying" terrorism. ' (Matthew Butler, Conscious Reporter Waking Times, Retrieved from http: //www. wakingtimes. com/2015/01/27/je-suis-hypocrisyselective-free-speech-secular-inquisition-france/).

10. See: http: //www. huffingtonpost. com/2015/01/07/financial-times-charlie-hebdo-stupid-muslim-baiting_n_6430242. $\mathrm{html}$ 